\title{
Immediate metabolic response to a low dose of insulin in children presenting with diabetes
}

\author{
J. D. BAUM, P. JENKINS, and A. AYNSLEY-GREEN \\ From the Department of Paediatrics, University of Oxford, John Radcliffe Hospital, Headington, Oxford
}

Baum, J. D., Jenkins, P., and Aynsley-Green, A. (1975). Archives of Disease in Childhood, 50, 373. Immediate metabolic response to a low dose of insulin in children presenting with diabetes. Seventeen new cases of diabetes in childhood were given an initial mean dose of insulin of 0.29 unit $/ \mathrm{kg}$ body weight by intramuscular injection (mean age of patient 7.4 years). This resulted in a fall in blood glucose over the first 2 hours at a mean rate of $88 \mathrm{mg} / 100 \mathrm{ml}$ per hour. Over the same time the mean total blood ketones fell from 3.23 to $2.3 \mathrm{mmol}$; and plasma insulin levels rose from a mean of $6 \mu \mathrm{U} / \mathrm{ml}$ to a mean of $65 \mu \mathrm{U} / \mathrm{ml}$. Thus, with this small initial dose of insulin the 2-hour plasma insulin values were within the range which in adults has been associated with a maximum fall in blood glucose concentration.

Three children with established diabetes presenting with ketoacidosis were also treated with a small initial dose of intramuscular insulin, $0.1 \mathrm{unit} / \mathrm{kg}$ in 2 of the patients and $0.5 \mathrm{unit} / \mathrm{kg}$ in the third. In 2 during a period of rehydration before insulin was given, blood glucose fell at a rate of $100 \mathrm{mg} / 100 \mathrm{ml}$ per hour. Over the 2 hours after the initial dose of insulin the mean rate of fall of blood glucose for all 3 patients was $73 \mathrm{mg} / 100 \mathrm{ml}$ per hour. None of these children developed hypoglycaemia nor hypokalaemia during treatment.

We conclude that an initial intramuscular injection of soluble insulin in the dose range of $0 \cdot 1-0.5$ units/kg body weight may be more appropriate and possibly safer for the treatment of diabetic ketoacidosis in children than the currently recommended larger doses divided between intravenous and intramuscular routes. Adequate rehydration must, however, remain the first priority in the management of such cases.

Many different regimens have been suggested for the management of diabetic ketoacidosis in childhood. In particular there is no agreement as to the size of the initial dose or route of adReceived 25 October 1974. ministration of insulin (Table I). Likewise there is no universal agreement as to the optimum management of adults in diabetic coma, though recently a persuasive argument has been put forward for using repeated small intramuscular doses of insulin

TABLE I

Recommended initial insulin dosage for treatment of children with diabetic ketoacidosis

\begin{tabular}{l|c|c}
\hline \multicolumn{1}{c|}{ Author } & Initial insulin dose & Route of administration (I.V.) \\
\hline Pond and Oakley (1968) & $10-20$ units & No route suggested \\
Cooke (1969) & $2 \cdot 0$ units $/ \mathbf{k g}$ & $\frac{1}{2}$ dose \\
Lloyd and Wolff (1969) & 1.0 unit $/ \mathbf{k g}$ & $\frac{1}{2}$ dose \\
Schwartz (1971) & $3-4$ units $/ \mathbf{k g}$ & $\frac{1}{2}$ dose \\
Hamilton (1972) & $40-80$ units & $\frac{1}{8}$ dose \\
Wood (1970) & 1.0 unit $/ \mathbf{k g}$ & $\frac{1}{2}$ dose \\
Krumlik and Ehrlich (1973) & 0.5 unit $/ \mathbf{k g}$ & Dose given subcutaneously \\
\hline
\end{tabular}


(Alberti, Hockaday, and Turner, 1973), or a continuous infusion of insulin (Page et al., 1974; Kidson et al., 1974; Semple, White, and Manderson, 1974). The proponents of these regimens claim that the administration of these small doses of insulin bring about a smooth fall in blood glucose concentration and reduce the risk of hypoglycaemia and hypokalaemia during recovery.

To assess the usefulness of this approach to the treatment of diabetic coma in childhood we have investigated the immediate metabolic and hormonal response to a small initial dose of soluble insulin in 17 children presenting with newly diagnosed diabetes. Because these children had not previously been treated with insulin, we hoped to record the plasma levels of insulin achieved with these doses without artefact due to the presence of circulating insulin antibodies, and to correlate these levels with the metabolic response observed. In the light of these studies we have treated similarly 3 cases of diabetic ketoacidosis in children with established diabetes.

\section{Materials and methods}

Clinical details of the 17 new cases of diabetes in childhood are presented in Table II. The mean age

TABLE II

Clinical details of 17 new diabetic children at the time of presentation (11 boys, 6 girls)

\begin{tabular}{l|c|c}
\hline & Mean & Range \\
\hline Age (years) & $7 \cdot 4$ & $1 \cdot 2-13 \cdot 7$ \\
Symptoms (w) & $5 \cdot 5$ & $0-20$ \\
Height (\%) & 60 & $10-97$ \\
Weight (\%) & 35 & $3-90$ \\
\hline
\end{tabular}

of the children was $7 \cdot 4$ years. The mean duration of symptoms was 5.5 weeks (range 0-20 weeks). At presentation there was a discrepancy between the centile rating for height and weight, indicating a recent weight loss. All patients had ketonaemia and ketonuria on admission; none was clinically dehydrated, acidotic, or comatose; and none was considered ill enough to require intravenous fluids.

A study was made of the immediate metabolic response to the first dose of insulin in these new cases of childhood diabetes. A baseline blood sample was drawn by peripheral venepuncture without veneconstriction. Soluble insulin was then given by intramuscular injection into the thigh and a further blood sample drawn 2 hours later. The mean dose of insulin used was 0.29 unit/kg body weight, range $0.07-0.82$ units $/ \mathrm{kg}$. Early cases received doses in the upper part of this range; more recent cases received smaller doses in the order of $0 \cdot 1$ unit $/ \mathrm{kg}$.

Details of the 3 children with established diabetes who presented with severe ketoacidosis are shown in Table III. All 3 cases were dehydrated and drowsy with acidotic breathing. In each case a baseline blood sample was drawn, an intravenous infusion of normal saline was started, and insulin was given by intramuscular injection into the thigh; subsequent blood samples were taken at 2-hourly intervals. The initial dose of insulin used was between $0 \cdot 1-0.5$ units/kg body weight.

$0.5 \mathrm{ml}$ whole blood was added to $5 \mathrm{ml}$ of $5 \%$ perchloric acid for assay of metabolites; $0.5 \mathrm{ml}$ blood was added to a lithium heparin tube for assay of plasma insulin and growth hormone; further $0.5 \mathrm{ml}$ aliquots of heparinized blood were taken for measurement of plasma free fatty acids and red cell 2, 3-diphosphoglycerate (2, $3 \mathrm{DPG}) ; 0.4 \mathrm{ml}$ blood was added to $0.1 \mathrm{ml}$ of aprotinin/EDTA for assay of plasma glucagon. Plasma electrolytes and osmolality were measured by the routine biochemistry laboratory.

Enzymatic methods were used for the measurement of blood glucose (Slein, 1965), lactate, and pyruvate (Hohorst Kreutz and Bucher, 1959), $\beta$-hydroxybutyrate and acetoacetate (Williamson, Mellanby, and Krebs, 1962), and glycerol (Kreutz, 1962). Free fatty acids were estimated colorimetrically by the method of Itaya and Ui (1965). Plasma insulin, growth hormone, and glucagon were measured by double antibody immunoassays and red cell 2, 3 DPG enzymatically according to the method of Keitt (1971).

Total blood ketone bodies represent the sum of the $\beta$-hydroxybutyrate and acetoacetate concentrations.

TABLE III

Clinical details of 3 patients with established diabetes at time of presentation with ketoacidosis

\begin{tabular}{|c|c|c|c|c|c|c|c|}
\hline Case no. & $\begin{array}{c}\text { Age } \\
\text { (years) }\end{array}$ & $\begin{array}{l}\text { Weight } \\
\text { (kg) }\end{array}$ & $\begin{array}{c}\text { Duration of } \\
\text { diabetes } \\
\text { (years) }\end{array}$ & $\begin{array}{l}\text { Normal daily } \\
\text { dose of } \\
\text { insulin } \\
\text { (units) }\end{array}$ & Dehydration & $\begin{array}{c}\text { Acidotic } \\
\text { breathing }\end{array}$ & $\begin{array}{l}\text { Level of } \\
\text { consciousness }\end{array}$ \\
\hline $\begin{array}{l}1 \\
2 \\
3\end{array}$ & $\begin{array}{r}5 \\
11 \\
14\end{array}$ & $\begin{array}{l}19 \\
47 \\
44\end{array}$ & $\begin{array}{l}2 \\
2 \\
9\end{array}$ & $\begin{array}{l}24 \\
52 \\
42\end{array}$ & $\begin{array}{l}\text { Severe } \\
\text { Severe } \\
\text { Severe }\end{array}$ & $\begin{array}{l}\text { Marked } \\
\text { Marked } \\
\text { Marked }\end{array}$ & $\begin{array}{l}\text { Precomatose* } \\
\text { Precomatose* } \\
\text { Precomatose* }\end{array}$ \\
\hline
\end{tabular}

$\star$ Drowsy but responsive to painful stimuli. 
Immediate metabolic response to a low dose of insulin in children presenting with diabetes

TABLE IV

Baseline biochemical data from new diabetic children at time of presentation

\begin{tabular}{|c|c|c|c|}
\hline & Mean & Range & Normal \\
\hline $\begin{array}{l}\text { Glucose }(\mathrm{mg} / 100 \mathrm{ml}) \\
\text { Ketones }(\mathrm{mmol} / \mathrm{l}) \\
\text { Lactate }(\mathrm{mmol} / \mathrm{l}) \\
\text { Bicarbonate }(\mathrm{mmol} / 1) \\
\text { Osmolality } \mathrm{mOsm} / \mathrm{kg} \mathrm{H} \mathrm{H}_{2} \mathrm{O}\end{array}$ & $\begin{array}{l}296 \\
3 \cdot 23 \\
1 \cdot 49 \\
21 \\
295\end{array}$ & $\begin{array}{c}137-690 \\
0 \cdot 2-9 \cdot 8 \\
0 \cdot 46-2 \cdot 66 \\
12-26 \\
276-309\end{array}$ & $\begin{array}{c}60-95 \\
0 \cdot 03-0 \cdot 09 \\
0 \cdot 50-1 \cdot 50 \\
19-25 \\
280-295\end{array}$ \\
\hline
\end{tabular}

\section{Results}

Biochemical data from the new diabetic cases on admission are summarized in Table IV. 6 of the children had blood glucose levels greater than 300 $\mathrm{mg} / 100 \mathrm{ml}$. Total blood ketone concentrations were raised with a mean value of $3.23 \mathrm{mmol} / 1$; in 2 cases the baseline total ketones were greater than 6 $\mathrm{mmol} / 1$, indicating profound ketosis. Blood lactate levels were only slightly raised. In only one child was the plasma bicarbonate concentration less than $15 \mathrm{mmol} / 1$. Plasma osmolality values were generally raised with a mean value of $295 \mathrm{mOsm} / \mathrm{kg} \mathrm{H}_{2} \mathrm{O}$, and in 5 cases values greater than 300 were seen.

The fall in blood glucose in 13 of the new diabetics after the initial intramuscular dose of insulin is shown in Fig. 1. Blood glucose fell from a mean

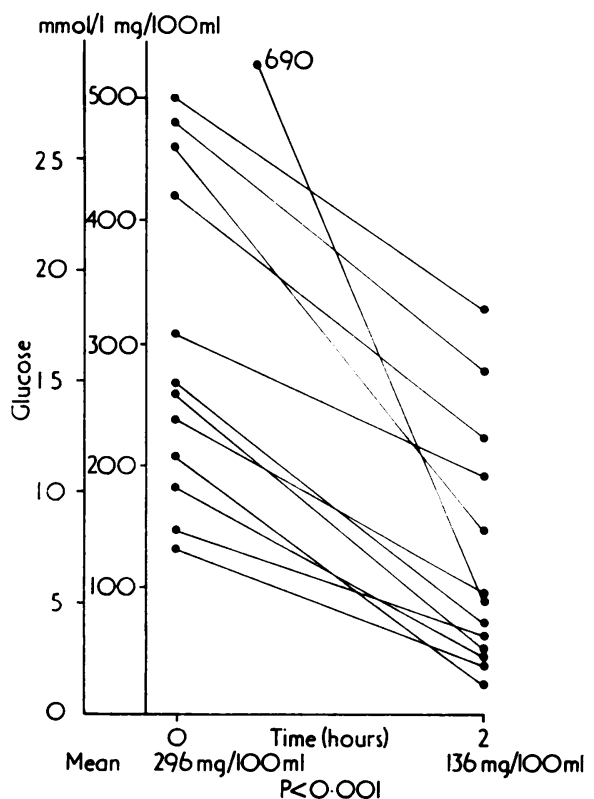

FIG. 1.-Fall in blood glucose in 13 new diabetic children after initial dose of insulin. Mean rate of fall was $88 \mathrm{mg} / 100 \mathrm{ml}$ per hour. of $296 \mathrm{mg} / 100 \mathrm{ml}$ to a mean of $136 \mathrm{mg} / 100 \mathrm{ml} 2$ hours after insulin. The mean rate of fall of blood glucose for the group was $88 \mathrm{mg} / 100 \mathrm{ml}$ per hour (range 42-200 $\mathrm{mg} / 100 \mathrm{ml}$ per hour).

The fall in total blood ketone concentration in 10 of the new diabetic patients after the first dose of insulin is shown in Fig. 2. Total blood ketone values fell from a mean of $3 \cdot 23$ to $2 \cdot 3 \mathrm{mmol} / \mathrm{l}$ 2 hours after insulin administration.

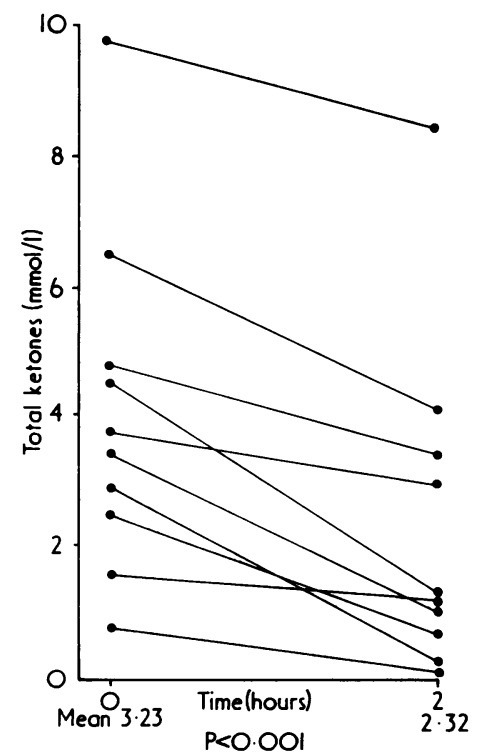

FIG. 2.-Fall in total blood ketone concentration in 10 new diabetic children after initial dose of insulin.

The change in plasma insulin levels in the same 10 children is shown in Fig. 3. A low level of plasma insulin was detectable in all cases initially, with a mean value of $6 \mu \mathrm{U} / \mathrm{ml}$. After the first injection of insulin this rose to a mean value of $65 \mu \mathrm{U} / \mathrm{ml}$ (range 25-102 $\mu \mathrm{U} / \mathrm{ml}$ ). There was no correlation between the dose of insulin administered per $\mathrm{kg}$ 
TABLE V

Biochemical data from new diabetic children before and 2 hours after initial dose of insulin

\begin{tabular}{|c|c|c|c|c|}
\hline & $\mathbf{O h}$ & $2 \mathrm{~h}$ & $\begin{array}{l}\text { No. of } \\
\text { paired } \\
\text { samples }\end{array}$ & $\mathbf{P}$ \\
\hline
\end{tabular}

Note: Mean values only are shown. All tests of significance were by paired ' $t$ ' test.

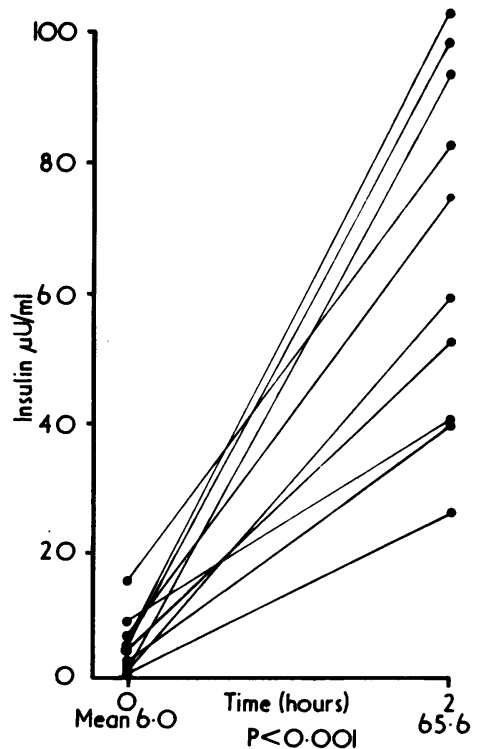

FIG. 3.-Rise in plasma insulin levels in 10 new diabetic children after initial dose of intramuscular insulin.

body weight and the plasma level of insulin measured at 2 hours.

Other results from the diabetic children are shown in Table V. There was a significant fall in the plasma potassium from a mean value of $4 \cdot 1$ to $3.38 \mathrm{mEq} / 12$ hours after insulin. The free fatty acid concentration fell from a mean of 1.63 to $0.88 \mathrm{mmol} / \mathrm{l}$. This fall was not significant. In one case there was an unaccountable rise in free fatty acid concentration. The values of 2, 3 DPG were normal initially and at 2 hours. Plasma glucagon and growth hormone levels were normal initially and 2 hours after insulin.

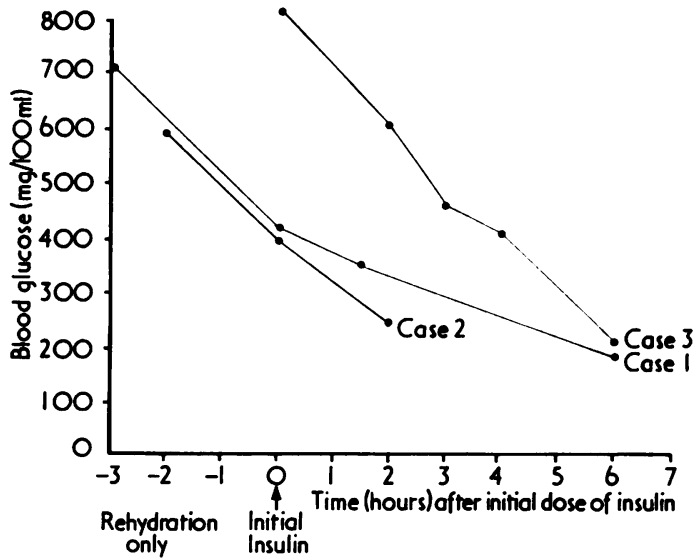

Fig. 4.-Fall in blood glucose in the 3 cases of ketoacidosis in children with established diabetes. The following doses of insulin were given: Case 1, 0.1 unit/kg at time 0 and 0.1 unit/kg at 3 hours; Case 2, 0.1 unit/kg at time 0; Case 3, 0.5 unit/kg at time 0 and 0.2 unit/kg at 3 hours and at 5 hours. Rehydration was in each case with $0.9 \%$ saline with added potassium at a concentration of $1 \mathrm{~g} \mathrm{KCl}$ in $500 \mathrm{ml}$.

Cases 1 and 2 were rehydrated at a rate of $10 \mathrm{ml} / \mathrm{kg}$ per hour for the first 3 hours and Case 3 at a rate of $20 \mathrm{ml} / \mathrm{kg}$ per hour for the first 3 hours.

Biochemical data for the 3 cases of severe ketoacidosis before treatment are shown in Table VI. The changes in blood glucose levels in these 3 cases after intravenous fluids and insulin are shown in Fig. 4. In 2 cases there was a period of rehydration alone before the initial dose of insulin was given. Over this period the rate of fall of blood glucose was $100 \mathrm{mg} / 100 \mathrm{ml}$ per hour in both cases. After insulin injection the blood glucose levels continued to fall with a mean rate of fall over the 2 hours after insulin of $73 \mathrm{mg} / 100 \mathrm{ml}$ per hour. The child 
TABLE VI

Baseline biochemical data from 3 patients with established diabetes at time of presentation with ketoacidosis

\begin{tabular}{|c|c|c|c|c|}
\hline Case no* & $\begin{array}{l}\text { Blood glucose } \\
(\mathrm{mg} / 100 \mathrm{ml})\end{array}$ & $\begin{array}{c}\text { Blood urea } \\
(\mathrm{mg} / 100 \mathrm{ml})\end{array}$ & $\begin{array}{c}\text { Bicarbonate } \\
(\mathrm{mmol} / \mathrm{l})\end{array}$ & $\begin{array}{l}\text { Urinary } \\
\text { ketones } \\
\text { (Acetest) }\end{array}$ \\
\hline $\begin{array}{l}1 \\
2 \\
3\end{array}$ & $\begin{array}{l}710 \\
590 \\
810\end{array}$ & $\begin{array}{l}81 \\
52 \\
42\end{array}$ & $\begin{array}{l}8 \\
8 \\
7\end{array}$ & $\begin{array}{l}+++ \\
+++ \\
+++\end{array}$ \\
\hline
\end{tabular}

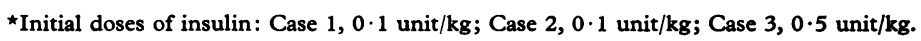

with the steepest absolute fall in glucose after insulin (Case 3) had received a larger dose of insulin $/ \mathrm{kg}$ body weight than the other 2 children $(0.5 \mathrm{unit} / \mathrm{kg}$ compared with $0.1 \mathrm{unit} / \mathrm{kg}$, respectively). However, there was no period of rehydration alone for comparison in this patient and the steep fall in blood glucose after insulin was similar to that in the other 2 patients before their first dose of insulin on intravenous fluids alone.

None of these 3 children developed hypoglycaemia during treatment. Other blood metabolite concentrations were not measured. Potassium supplements were included in the saline infusion and no child developed hypokalaemia.

\section{Discussion}

Many regimens have been suggested for the management of diabetic ketoacidosis both in children and in adults. The initial dose of insulin recommended for children with ketoacidosis varies from $0 \cdot 5-4$ units $/ \mathrm{kg}$ body weight to absolute units of insulin without reference to body weight or size (Table I) as recommended by some. Likewise there is variation in the recommended route of insulin administration.

In normal adult subjects a maximum fall in blood glucose concentration is achieved by maintaining plasma insulin levels in the range of 20-200 $\mu \mathrm{U} / \mathrm{ml}$ (Sönksen et al., 1973). Sönksen et al. (1972) have also shown that the rate of fall of blood glucose in adults with diabetic ketoacidosis is uniformly rapid when plasma concentrations of insulin are within this range. In order to achieve such levels during the treatment of ketoacidosis recent workers have suggested repeated small intramuscular doses of insulin (Alberti et al., 1973), or continuous intravenous infusion of insulin (Page et al., 1974; Kidson et al., 1974; Semple et al., 1974).

It has been the usual practice in the management of children with diabetic ketoacidosis to administer half of the insulin as a bolus by intravenous injection and half by intramuscular or subcutaneous injection. In adults the practice of giving a bolus of intravenous insulin has been criticised because of the short half-life of insulin in vivo. Thus, Turner et al. (1971) have shown insulin to have a half-life of between 4 and 8 minutes, and 25 minutes after intravenous injection serum concentrations fall to less than $1 \%$ of the initial peak values measured. On the other hand, large intramuscular doses of insulin could create resevoirs with erratic release of insulin into the systemic circulation. Furthermore, Alberti et al. (1973) have shown that combined intravenous and intramuscular administration of insulin can result in extremely high plasma levels of insulin which may fail to suppress adrenalineinduced lipolysis (Lavis and Williams, 1973).

For these reasons we have investigated the effects of giving an initial small intramuscular dose of insulin to new cases of diabetes in children and of giving repeated small doses in cases of ketoacidosis in children with established diabetes. In the new cases the mean rate of fall of blood glucose was $88 \mathrm{mg} / 100 \mathrm{ml}$ per hour after the initial intramuscular dose of insulin. This rate of fall is similar to that reported by Alberti et al. (1973) in adult diabetics with ketoacidosis treated with a similar regimen. The plasma levels of insulin achieved in these children 2 hours after the initial dose of insulin were within the range recommended by Sönksen et al. (1973) with a mean value of $65 \mu \mathrm{U} / \mathrm{ml}$. The children with lower plasma insulin concentrations had a similar rate of fall in blood glucose as those with the higher plasma concentrations. There was no correlation between the dose of insulin and the insulin levels measured at 2 hours. This presumably reflects variation in the rate of absorption of insulin from the intramuscular depots, variations in insulin metabolism, and the practical difficulties of accurately administering small doses of insulin from a standard solution containing 20 units $/ \mathrm{ml}$.

In the 3 children presenting with ketoacidosis similar small doses of insulin were given intra- 
muscularly (ranging from $0 \cdot 1-0.5$ units $/ \mathrm{kg}$ body weight). In 2 cases the insulin therapy was preceded by a period of rehydration alone with $0.9 \%$ saline. The rate of fall of blood glucose concentration was greater during this period than in the 2 hours after insulin. This emphasizes the importance of fluid replacement in the management of this condition and is in accord with the observations of Page et al. (1974) in adults. In all 3 cases the hyperglycaemia was controlled without hypoglycaemia or hypokalaemia occurring.

From the results obtained in the new diabetic children we conclude that an intramuscular injection of insulin of between $0 \cdot 1$ and $0 \cdot 2$ units $/ \mathrm{kg}$ will achieve an effective plasma insulin concentration. We do not have a measure of the plasma insulin concentration in the cases of established diabetes, but from the rate of fall of blood glucose in these cases we can state that the dose of insulin given was effective.

We suggest, therefore, that intramuscular injection of soluble insulin in dosage of 0.1 to 0.5 units $/ \mathrm{kg}$ body weight may be more appropriate and possibly safer in the treatment of diabetic ketosis in children than the use of larger divided doses given intravenously and intramuscularly as currently recommended.

We thank all members of the nursing, medical, and laboratory staff who have helped in these studies; Dr. R. C. Turner, for insulin and growth hormone estimations; Dr. S. Bloom, for glucagon estimation; Dr. P. Emerson for measuring the red cell 2, 3 DPG levels; and Dr. T. D. R. Hockaday and Professor K. G. Alberti for help and encouragement.

\section{REFERENCES}

Alberti, K. G. M. M., Hockaday, T. D. R., and Turner, R. C. (1973). Small doses of intramuscular insulin in the treatment of diabetic coma. Lancet, 2, 515.

Cooke, R. E., (1969). Parenteral fluid therapy. Textbook of Pediatrics, 9th ed., p. 224. Ed. by W. E. Nelson. Saunders, Philadelphia.

Hamilton, W. (1972). Clinical Paediatric Endocrinology, p. 93. Butterworths, London.

Hohorst, H. J., Kreutz, F. H., and Bucher, T. (1959). Uber Metabolitgehalte und metabolitkonzentrationen in der leber der ratte. Biochemische Zeitschrift, 332, 18.
Itaya, K., and Ui, M. (1965). Colorimetric determination of free fatty acids in biological fruits. Fournal of Lipid Research, 6 16.

Keitt, A. S. (1971). Reduced nicotinamide adenine dinucleotide -linked analysis of 2, 3-diphosphoglyceric acid: Spectrophotometric and fluorometric procedures. Fournal of Laboratory and Clinical Medicine, 77, 470.

Kidson, W., Casey, J., Kraegen, E., and Lazarus, L. (1974). Treatment of severe diabetes mellitus by insulin infusion. British Medical fournal, 2, 691.

Kreutz, F. H., (1962). Enzymatische glycerinbestimmung. Klinische Wochenschrift, 40, 362.

Krumlik, J. J., and Ehrlich, R. M. (1973). Insulin and sodium bicarbonate treatment of diabetic acidosis: retrospective review. Fournal of Pediatrics, 83, 268.

Lavis, V. R., and Williams, R. H. (1973). Lipolytic effects of high concentrations of insulin on isolated fat cells. Diabetes, 22, 629.

Lloyd, J. K., and Wolff, O. H. (1969). Diabetes mellitus. Paediatric Endocrinology, p. 453. Ed. by D. V. Hubble. Blackwell Scientific Publications, Oxford.

Page, M. McB., Alberti, K. G. M. M., Greenwood, R, Gumaa K. A., Hockaday, T. D. R., Lowy, C., Nabarro, J. D. N. Pyke, D. A., Sonksen, P. H., Watkins, P. J., and West, T. E. T. (1974). Treatment of diabetic coma with continuous low-dose infusion of insulin. British Medical fournal, 2, 687.

Pond, H., and Oakley, W. G. (1968). Diabetes in children. Clinical Diabetes and Its Biochemical Basis, p. 606 . Ed. by W. G. Oakley, D. A. Pyke, and K. W. Taylor. Blackwell Scientific Publications, Oxford.

Schwartz, R. (1971). The critically ill child: diabetic ketoacidosis and coma. Pediatrics, 47, 902.

Semple, P. F., White, C., and Manderson, W. G. (1974). Continuous intravenous infusion of small doses of insulin in treatment of diabetic ketoacidosis. British Medical fournal, 2, 694.

Slein, M. W. (1965). D-Glucose determination with hexokinase and glucose-6-phosphate dehydrogenase. Methods of Enzymatic Analysis, p. 117. Ed. by H. U. Bergmeyer. Chemie, Weinheim; Academic Press, New York.

Sönksen, P. H., Srivastava, M. C., Tompkins, C. V., and Nabarro, J. D. N. (1972). Growth hormone and cortisol responses to insulin infusion in patients with diabetes mellitus. I.ancet, 2 , 155.

Sönksen, P. H., Tompkins, C. V., Srivastava, M. C., and Nabarro, J. D. N. (1973). A comparative study on the metabolism of human insulin and porcine proinsulin in man. Clinical Science and Molecular Medicine, 45633.

Turner, R. C., Grayburn, J. A., Newman, G. B., and Nabarro, J. D. N. (1971). Measurement of the insulin delivery rate in man. Fournal of Clinical Endocrinology, 33, 279.

Williamson, D. H., Mellanby, J., and Krebs H. A. (1962). Enzymic determination of $\mathrm{D}(-)-\beta$-hydroxybutyric acid and acetoacetic acid in blood. Biochemical fournal, 82, 90.

Wood, B. S. B. (1970). A Paediatric Vade-Mecum, 7th ed., p. 92. Lloyd-Luke, London.

Correspondence to Dr. J. D. Baum, Department of Paediatrics. John Radcliffe Hospital, Headington, Oxford OX3 9DU. 